\title{
Motivations for and barriers to populations becoming more involved in local flood management, using Orford, Suffolk, as a case study
}

\author{
Jacqueline Smith; Alan Bond; Peter Simmons. \\ University of East Anglia, Norwich, NR4 7TJ, UK \\ jacqueline.smith@uea.ac.uk
}

\begin{abstract}
Without effective consultation and some public participation in decision making concerning river and coastal defences, outcomes are less likely to be acceptable, and local people may become disillusioned with the process (Myatt et al. 2003; Milligan and O'Riordan 2004). Given that there are various ways to facilitate inclusion, this research focuses on the reasons why local people do or do not get involved in flood management issues, and what might lead to more involvement.

We use a mixed method approach involving a questionnaire survey, individual interviews and $Q$ methodology. A survey of village residents identified current levels of knowledge and involvement in the local population. The measurement of levels of knowledge was considered to be an important prerequisite to involvement but other motivations and barriers were also sought. A cross-section of questionnaire respondents was selected to elicit statements for a subsequent $Q$-sorting exercise. $Q$ methodology was used to identify different views on engagement which exist in relation to involvement in flood management. Finally, further interviews will be conducted with citizens associated with each perspective. The aim of the study is to inform the development of appropriate stakeholder engagement techniques that lead to increased, more inclusive participation amongst the public.
\end{abstract}

\section{Keywords: public participation, flood management, Q methodology.}

\section{Background to Research.}

One consequence of climate change is an increased risk of flooding for many coastal communities, and decisions have to be made regarding flood management. A significant factor in the acceptability of flood management strategies is the extent to which the public have been engaged. Without effective consultation and some public participation in decision making concerning river and coastal defences, outcomes are less likely to be acceptable, and local people may become disillusioned with the process (Myatt et al. 2003; Milligan and O'Riordan 2004) However, ensuring engagement of a representative cross section of a community has proved to be problematic.

A common perception, is that local populations lack understanding of the issues involved (Sturgis and Allum 2004; Lorenzoni et al. 2007) and therefore will not participate in management decisions. Although it is also recognised that lack of scientific understanding and knowledge about flood management is not the only barrier to inclusion (Buckeley 2000) it is one that it is important to consider. The hypothesis from which this research therefore proceeded was that the motivation to become engaged in coastal planning is contingent on the knowledge of the threat of flooding. However, public agencies, such as the Environment Agency in the UK, which have to explain policy flood management options to the public, have in the past been criticised for being insufficiently aware of the existing knowledge of the intended audience (Miller 2001; Johnson. and Chess, 2006). Understanding current levels of 
knowledge and involvement in a local population could therefore give insights into factors that enable or obstruct further community involvement in flood management decisions.

The East Coast of England has been identified as one that will be particularly at risk from sea level rise.(Hulme et al. 2002; Pye 2005) The Suffolk and Essex coast is also currently being studied in a comprehensive review for future defence strategy by the Environment Agency. It is therefore a potentially 'live' issue for local people. The village of Orford in Suffolk was therefore selected as a case study where the degree of present knowledge and involvement in flood management of the local population could be assessed. It has similar demographic characteristics and history of flood management to other vulnerable towns and villages along the coastline of Suffolk.

\section{Research Methodology}

The research employed a mixed method design involving a questionnaire survey, individual interviews and $Q$ methodology.

\subsection{Questionnaire}

A questionnaire was used to determine current levels of knowledge about and involvement in flood management. Knowledge of respondents was assessed based on their understanding of the causes and consequences of coastal flooding and of responsibilities for flood management. Responses to these questions were used to calculate an overall knowledge score for each respondent. Indicators of current levels of involvement included membership of flood management-related organisations or groups, and/or the attendance at flood management meetings by respondents. Questionnaires were distributed to the 432 households, also to a drama group to access younger people in the village. 110 questionnaires were received from a distribution to all the households and group in the village. Questionnaires were also left in the village post office, newsagents, pubs, garage and restaurants and returns noted by address when it was given. Respondents were then classified into five groups of people with varying levels of knowledge and involvement. High and low scores were defined as those greater than one standard deviation from the mean, with others in a 'no classification' category (Figure 1).

\begin{tabular}{|c|c|c|c|}
\hline $\begin{array}{l}\text { High } \\
\text { Knowledge }\end{array}$ & $\mathrm{HH}$ & $\mathrm{HL}$ & $\begin{array}{l}\text { High } \\
\text { Knowledge }\end{array}$ \\
\hline $\begin{array}{l}\text { High } \\
\text { Involvement }\end{array}$ & \multicolumn{2}{|c|}{ No Classificatior } & $\begin{array}{l}\text { Low } \\
\text { Involvement }\end{array}$ \\
\hline $\begin{array}{l}\text { Low } \\
\text { Knowledge }\end{array}$ & & & $\begin{array}{l}\text { Low } \\
\text { Knowledge }\end{array}$ \\
\hline $\begin{array}{l}\text { Low } \\
\text { Involvement }\end{array}$ & $\begin{array}{l}\text { LL } \\
\text { (19) }\end{array}$ & $\begin{array}{l}\mathrm{LH} \\
\text { (7) }\end{array}$ & $\begin{array}{l}\text { High } \\
\text { Involvement }\end{array}$ \\
\hline
\end{tabular}

Figure 1. Classification of Knowledge and Involvement. (7) = respondents in each classification.

\subsection{Interviews.}

Interviews were carried out with a sub-set of respondents with contact details drawn from four of the five classifications, ( 5 out of $18 \mathrm{HH}, 3 / 9 \mathrm{HL}, 4 / 9 \mathrm{LL}, 3 / 7 \mathrm{LH}$ ). Some categories were more difficult to access than others due to fewer potential interviewees with contact details. The NC category will be accessed for further interviews. Initially more potentially extreme views were sought. Interviews were transcribed and analysed using NVivo (Bazeley 2007). Based on a study of the literature, combined with analysis of transcripts, key issues were 
identified which fell into four categories: individual issues; consultation and participation issues; governance issues and information issues. Forty statements, ten from each category, were selected from the transcripts to represent the key issues identified. This set of statements was then used for the Q-sorting exercise (McKeown and Brown 1988).

\subsection{Q Methodolology.}

$Q$ methodology is a research method that involves selected respondents sorting a series of statements in order to represent their views on a topic. Analysis of the resulting data set enables grouping of respondents according to the extent to which their sorts reveal either shared or significantly different viewpoints. This method has been used in larger studies for investigating perceptions and understandings of risk in a variety of geographical contexts (Simmons and Walker 1999; Eden et al. 2005; Previte et al. 2007) as well as in studies that have sought a more successful public participation process in decision making and environmental assessment (Webler and Tuler 2006)

Participants were instructed to sort the set of statements according to the extent that statements were "most like my views" or "least like my views". The data from the sorting exercise were analysed with PQMETHOD software (Schmolck 2002) using Principal Components Analysis with Varimax rotation to identify shared viewpoints. The analysis produced a five-factor solution, with each factor representing a distinct perspective on participation in local flood management.

Thirty-two of the forty participants loaded significantly (at least $p=0.05$ ) onto one of the 5 factors. Having identified the factor, or viewpoint, with which they were associated, respondents were further differentiated, using their responses to the survey questionnaire, according to their levels of knowledge and involvement, their gender and age (see Tables 2, 4, 6, 8 and 10). Follow-up interviews and a workshop are planned in the concluding stages of the research,

\section{Results}

There follows a description of the characteristics of each of the Factors identified by PQMETHOD. Each Factor has attributing statements, and the numbers after each statement number refers to the strength of the $Z$ scores of each statement. $Z$ scores reflect the weightings of responses for each statement by the 40 participants. Those statements that reflect scores above 1 and considered 'most like my views' and 'least like my views', were used for analyse, the higher the $Z$ score the higher the loading on the statement. Each factor characteristic description includes: the significant statements; and characteristics of the respondent; followed by an analysis of the barriers, motivations and attributes of each factor

\subsection{Characteristics of Factor 1 - Confident Knowledgeable Respondents.}

\begin{tabular}{|l|l|}
\hline Statements most like my views & Statements least like my views \\
\hline $\begin{array}{l}\text { 13. I think consultation works and decisions } \\
\text { accepted if there is real honesty, and they tell you } \\
\text { how it is. }\end{array}$ & $\begin{array}{l}\text { 38. Scientists make a fuss about global warming because } \\
\text { they want extra funding for their research, so they make it } \\
\text { sound worse than it is. }\end{array}$ \\
\hline $\begin{array}{l}\text { 35. The Alde and Ore Association informs us of } \\
\text { what is going on in flood management. }\end{array}$ & 8. I don't think flooding will happen in my lifetime. \\
\hline $\begin{array}{l}\text { 7. I am involved because I have an interest in } \\
\text { farming, sailing and protecting wildlife. }\end{array}$ & 6. I think my opinion will not make a difference \\
\hline $\begin{array}{l}\text { 39. Information about flood management should be } \\
\text { less complicated and intimidating, easy to read, } \\
\text { and people should be comfortable to ask }\end{array}$ & 1. I am busy doing other things \\
\hline
\end{tabular}


\begin{tabular}{l|l|l}
\hline questions. & 1.3 & \\
\hline Table 1. Selected significant statements for Factor 1.
\end{tabular}

The main characteristics of Factor 1 as compared with the other Factors, is a concern with the process of consultation. It was the only factor that had regard to the quality of the information provided for people, and participants being more involved because of a motivating interest. Significantly, scientists are not thought to bias data. Along with Factors 3, 4 and 5 there was a disagreement that flooding would not happen in their lifetime.

\begin{tabular}{|l|l|l|l|l|l|l|l|l|}
\hline 03HHF4 & $36 \mathrm{HHF} 4$ & 28HHM4 & 11HLM3 & 26HHF4 & 06HLF4 & 07HLF4 & $08 \mathrm{NCM} 4$ & $15 \mathrm{HHM} 4$ \\
0.69 & 0.64 & 0.61 & 0.62 & 0.61 & 0.59 & 0.51 & 0.51 & 0.48 \\
\hline
\end{tabular}

Table 2. Defining sorts correlating people to their loadings on Factor 1.

The key to Tables 2, 4, 6, 8 and 10 are: The first two numbers relate to the participant returning the sort, 0-40; the next two numbers relate to the levels of knowledge and involvement, $H=$ High and $L=$ Low, NC is no category; the next letter is the gender; the next number, the age $<20=1 ; 20-40=2 ; 40$ $60=3 ;>60=4$. The number below in each cell is the significance of the sort above Standard Error $S E=4.1$.

\subsubsection{Motivations and Attributes of people loading on Factor 1.}

$>$ Express an interest in the way information is presented and its accessibility.

$>$ Would belong to the Alde and Ore Association (all the participants who loaded on Factor 1 belonged to the Association; membership was not so significant in people in the other factors'.

$>$ Could become involved because of personal interests.

$>$ All the participants who loaded on this category were in the older age groups (40+).

$>$ There were a high proportion, (8 out of 9 ), high knowledge participants.

\subsection{Characteristics of Factor 2 - Politically Aware Respondents.}

\begin{tabular}{|c|c|}
\hline Statements most like my views & Statements least like my views \\
\hline $\begin{array}{l}\text { 32. Central Government is facing severe cash } \\
\text { problems. East Suffolk does not return Labour } \\
\text { MPs, so they will not spend money here. }\end{array}$ & 1. I am busy doing other things. \\
\hline $\begin{array}{l}\text { 26. The Environment Agency doesn't feel the small } \\
\text { number of people involved, are worth the billions } \\
\text { that it is going to cost to save the coastline. }\end{array}$ & $\begin{array}{l}\text { 37. I would trust the Environment Agency not to tell lies. } \\
1.5\end{array}$ \\
\hline $\begin{array}{l}\text { 27. Local Councils should be the principal agents } \\
\text { for sea defences. }\end{array}$ & $\begin{array}{l}\text { 3. If it was a practical situation and flooding was actually } \\
\text { happening, then yes I would get involved. }\end{array}$ \\
\hline $\begin{array}{l}\text { 29. The Alde and Ore Association are an important } \\
\text { pressure group. }\end{array}$ & 28. We need to talk to local councillors more. \\
\hline
\end{tabular}

Table 3. Selected significant statements for Factor 2.

A majority of the characteristics in Factor 2 constitute political concerns. One of the main issues identified was lack of funding by both Central Government and the Environment Agency. Further political references in this factor are to local councils, and a local group, the Alde and Ore Association which is perceived in this factor choice as a local pressure group (not as an information source as in Factor 1). There was an apparent lack of trust in the Environment Agency.

Table 4 Defining sorts correlating people to their loadings on Factor 2.

\begin{tabular}{|l|l|l|l|l|l|}
\hline $10 \mathrm{NCF3}$ & $05 \mathrm{LHM} 4$ & $18 \mathrm{HHM} 4$ & $27 \mathrm{HHM} 4$ & $33 \mathrm{HHF} 4$ & $01 \mathrm{LLF3}$ \\
0.76 & 0.71 & 0.68 & 0.67 & 0.58 & -0.47 \\
\hline
\end{tabular}




\subsubsection{Barriers and Attributes of people loading on Factor 2.}

$>$ Recognises there is a problem with funding.

$>$ Local councils should be responsible, but more dialogue with their elected members is not favoured.

$>$ Has a problem with trust in the Environment Agency.

$>$ The participants who loaded in this factor were in the older age groups (40+).

$>$ There were mixed amounts of knowledge and involvement.

\subsection{Characteristics of Factor 3 - Sceptical Pragmatic Respondents}

\begin{tabular}{|c|c|}
\hline Statements most like my views & Statements least like my views \\
\hline $\begin{array}{l}\text { 3. If it was a practical situation and flooding was } \\
\text { actually happening, then yes I would get involved. }\end{array}$ & $\begin{array}{l}\text { 33. I think some of the exhibition was difficult to take on } \\
\text { board because it was technical. }\end{array}$ \\
\hline $\begin{array}{l}\text { 38. Scientists make a fuss about global warming } \\
\text { because they want funding for their research, so } \\
\text { they make it sound worse than it is. }\end{array}$ & $\begin{array}{l}\text { 34. People do not believe in sea level rise, and don't } \\
\text { accept we are doing damage. }\end{array}$ \\
\hline $\begin{array}{l}\text { 13. I think consultation works and decisions are } \\
\text { accepted if there is real honesty and they tell you } \\
\text { how it is. }\end{array}$ & 6. I think my opinion will not make a difference. \\
\hline $\begin{array}{l}\text { 35. The Alde and Ore Association inform us of } \\
\text { what is going on in flood management. }\end{array}$ & 8. I don't think flooding will happen in my lifetime. \\
\hline $\begin{array}{l}\text { 12. People are cynical of politicians. I think they } \\
\text { have a hidden agenda. } \\
\end{array}$ & $\begin{array}{l}\text { 11. Finding out by word of mouth, like the village shop is } \\
\text { terribly important to us. }\end{array}$ \\
\hline
\end{tabular}

Table 5. Selected significant statements for Factor 3.

There are similarities between this Factor and Factor 1. Like Factor 1, participants felt there should be honesty in the process of consultation, and information about management is obtained from the Alde and Ore Association. However, significantly in this Factor, there was a willingness to get involved in flooding if it was actually happening, and a view that other people do not believe in sea level rise. There was also a certain amount of confidence in being able to find a local exhibition about flood management options not too difficult, or technical.

\begin{tabular}{|l|l|l|l|l|}
\hline $09 N C M 4$ & $02 \mathrm{LLM} 1$ & $37 \mathrm{NCM}$ & $39 \mathrm{HLM} 4$ & $21 \mathrm{HLM} 1$ \\
0.61 & 0.59 & 0.55 & 0.50 & 0.47 \\
\hline
\end{tabular}

Table 6. Defining sorts correlating people to their loadings on Factor 3

\subsubsection{Motivations, Barriers and Attributes of people loading on Factor 3.}

$>$ Would get involved if there was flooding. This statement stood out as different from other factors and characterised Factor 3 people.

$>$ An apparent lack of trust in scientists.

$>$ A need for honesty in consultation, and an implied confidence that their opinions would be listened to.

$>$ Use of an information source like the Alde and Ore Association and possibly not the village shop.

$>$ They were all males who loaded on Factor 3. Most participants in this factor had low current involvement in flood management.

$>$ There was a distribution of age groups in the factor including two under 20.

\subsection{Characteristics of Factor 4 - Sceptical and Locally Attuned Respondents}




\begin{tabular}{|c|c|}
\hline Statements most like my views & Statements least like my views \\
\hline $\begin{array}{l}\text { 31. I get information about flood management from } \\
\text { local people. }\end{array}$ & $\begin{array}{l}\text { 38. Scientists make a fuss about global warming because } \\
\text { they want extra funding for their research, so they make it } \\
\text { sound worse than it is. }\end{array}$ \\
\hline $\begin{array}{l}\text { 14. I would listen to someone normal, someone } \\
\text { who used the river the same as I do. } \\
\text {. }\end{array}$ & $\begin{array}{l}\text { 32. Central government is facing severe cash problems. } \\
\text { East Suffolk does not return labour MPs, so they will not } \\
\text { spend money here. }\end{array}$ \\
\hline $\begin{array}{l}\text { 12. People are cynical of politicians. I think they } \\
\text { have a hidden agenda. } \\
1.7\end{array}$ & $\begin{array}{l}\text { 39. Information about flood management should be less } \\
\text { complicated and intimidating, easy to read, and people } \\
\text { should be comfortable to ask questions. }\end{array}$ \\
\hline $\begin{array}{l}\text { 21. People are keen to get involved at the } \\
\text { beginning but there is a lot of cynicism now } \\
\text { because nothing has happened. }\end{array}$ & 8. I don't think flooding will happen in my lifetime. \\
\hline $\begin{array}{l}\text { 20. Local people involved in flood management } \\
\text { should be invited to debriefings. }\end{array}$ & $\begin{array}{l}\text { 30. I get information from noticing local things like the } \\
\text { flood line on the side of the Town Hall after the } 1953 \\
\text { flood. }\end{array}$ \\
\hline
\end{tabular}

Table 7. Selected Significant Statements for Factor 4

Factor 4 had more statements concerning local information sources than the other factors. There were statements selected for getting information from local people. The importance of local people being involved in debriefings was also significant. There was a tendency for cynicism, in both people's views of politicians because they have hidden agendas, and the consultation process, where nothing has been happening, when people were keen to get involved at the beginning.

\begin{tabular}{|l|l|l|l|l|l|}
\hline 24LLF2 & 32LLF1 & 34NCF3 & 13LHF4 & 30NCF3 & 12LLF4 \\
0.62 & 0.61 & 0.48 & 0.46 & 0.45 & 0.41 \\
\hline
\end{tabular}

Table 8 Defining sorts correlating people to their loadings on Factor 4

\subsubsection{Motivations, Barriers and Attributes of people loading on Factor 4.}

$>$ A possible preference for gaining information from local people.

$>$ Some issues about politicians and the consultation process.

$>$ An implied trust in scientists.

$>$ They were all females who loaded in Factor 4.

$>$ All age groups were represented. Participants had mostly low to average knowledge and involvement scores.

\subsection{Characteristics of Factor 5 - Dichotomous Respondents}

\begin{tabular}{|c|c|}
\hline Statements most like my point of view & Statements least like my point of view \\
\hline $\begin{array}{l}\text { 32. Central Government is facing severe cash } \\
\text { problems. East Suffolk does not return Labour } \\
\text { MPs, so they will not spend money here. }\end{array}$ & $\begin{array}{l}\text { 18. If they have made up their mind before consultation, } \\
\text { there is no real choice, and it is a waste of time } \\
1.9\end{array}$ \\
\hline $\begin{array}{l}\text { 25. I am told there are many good people in the } \\
\text { Environment Agency. They are well trained, want } \\
\text { to do a good job, and find the money. }\end{array}$ & $\begin{array}{l}\text { 2. I would join an organisation like the Alde and Ore to } \\
\text { get involved. } \\
1.7\end{array}$ \\
\hline 22. People ought to write and protest more. & $\begin{array}{l}\text { 26. The Environment Agency doesn't feel that the small } \\
\text { number of people involved are worth the billions that it is } \\
\text { going to cost to save the coastline. }\end{array}$ \\
\hline 6. I think my opinion will not make a difference.1.2 & 8. I don't think flooding will happen in my lifetime. 1.5 \\
\hline 28. We need to talk to local councillors $\mathrm{m}$ & $\begin{array}{l}\text { 7. I get involved because I have an interest in farming, } \\
\text { sailing or wildlife protection. }\end{array}$ \\
\hline
\end{tabular}

Table 9. Selected significant statements for Factor 5 
The main characteristic of Factor 5 is that some of the statements representing the factor were the reverse of those selected by participants in the other factors. Some participants were not getting involved due to a personal interest or joining the Alde and Ore Association, both the reverse in Factor 1. Other contrasts were that the Environment Agency was well thought of, and more dialogue was needed with local councillors, both the reverse of Factor 2 .

\begin{tabular}{|l|l|l|l|l|l|}
\hline 35NCM4 & $04 \mathrm{HHF} 4$ & 38HHM4 & 25HHM3 & 22NCM3 & 20NCM4 \\
-0.72 & -0.56 & 0.54 & 0.52 & -0.51 & 0.46 \\
\hline
\end{tabular}

Table 10. Defining sorts correlating people to their loadings on Factor 5

\subsubsection{Motivations, Barriers and Attributes of people loading on Factor 5}

$>$ Some support for the Environment Agency to do a good job.

$>$ Doubts about personal involvement.

> Some have an opinion that people ought to engage and protest more.

$>$ Respondents had both negative and positive responses to statements.

$>$ The selectors of Factor 5 were in the older age groups and in the $\mathrm{HH}$ and

NC categories.

\section{Conclusions.}

The table below displays significant aspects of the results that will need verifying. There are similarities in the barriers perceived with regard to honesty and trust issues, however there are some differences in the motivation and improvement possibilities that will provide a basis for further questioning. Other findings requiring further investigation, that have emerged from the study, are the differences between the motivations of and possible engagement preferences of the high levels of knowledge people associated with Factors 1 and 5, and the lower level knowledge and involvement people associated with Factors 3 and 4.

\begin{tabular}{|c|c|c|c|c|c|c|}
\hline Factor & Barrier/s & $\begin{array}{l}\text { Motivations } \\
\text { implied }\end{array}$ & $\begin{array}{l}\text { Improvement } \\
\text { possibilities }\end{array}$ & $\begin{array}{l}\text { Knowledge/ } \\
\text { Involvement }\end{array}$ & Gender & Age \\
\hline $\begin{array}{l}1 \\
\text { Confident and } \\
\text { Knowledgeable }\end{array}$ & $\begin{array}{l}\text { Lack of } \\
\text { honesty. }\end{array}$ & $\begin{array}{l}\text { Personal } \\
\text { interest. } \\
\text { Confidence. } \\
\text { Have time. }\end{array}$ & $\begin{array}{l}\text { Good } \\
\text { information. }\end{array}$ & $\begin{array}{l}\text { High } \\
\text { knowledge. } \\
\text { Mixed } \\
\text { involvement. }\end{array}$ & $\begin{array}{l}\text { Males } \\
\text { and } \\
\text { Females }\end{array}$ & $40+$ \\
\hline $\begin{array}{l}2 \\
\text { Politically } \\
\text { Aware }\end{array}$ & $\begin{array}{l}\text { Lack of } \\
\text { funding. } \\
\text { Lack of trust. } \\
\text { Not } \\
\text { practical. }\end{array}$ & Have time. & $\begin{array}{l}\text { Local Councils } \\
\text { and Pressure } \\
\text { Group used. }\end{array}$ & $\begin{array}{l}\text { Mixed } \\
\text { Knowledge } \\
\text { and } \\
\text { Involvement }\end{array}$ & $\begin{array}{l}\text { Males } \\
\text { and } \\
\text { Females }\end{array}$ & $40+$ \\
\hline $\begin{array}{l}3 \\
\text { Sceptical and } \\
\text { Pragmatic }\end{array}$ & $\begin{array}{l}\text { Lack of } \\
\text { honesty. } \\
\text { Lack of trust } \\
\text { in scientists } \\
\text { and } \\
\text { politicians. }\end{array}$ & $\begin{array}{l}\text { A practical } \\
\text { situation to } \\
\text { respond to. }\end{array}$ & $\begin{array}{l}\text { Good } \\
\text { information. }\end{array}$ & $\begin{array}{l}\text { Mixed } \\
\text { knowledge. } \\
\text { Low to } \\
\text { average } \\
\text { involvement. }\end{array}$ & All Males & $\begin{array}{l}\text { Under } \\
20 \text { to } \\
+60 \\
\text { but no } \\
20-40\end{array}$ \\
\hline $\begin{array}{l}4 \\
\text { Sceptical and } \\
\text { Locally attuned }\end{array}$ & Cynicism. & $\begin{array}{l}\text { Local source } \\
\text { of information, } \\
\text { prefer oral? }\end{array}$ & More feedback. & $\begin{array}{l}\text { Mostly low to } \\
\text { average } \\
\text { knowledge } \\
\text { and } \\
\text { involvement }\end{array}$ & $\begin{array}{l}\text { All } \\
\text { Females }\end{array}$ & $\begin{array}{l}\text { All age } \\
\text { groups } \\
\text { Under } \\
20-60_{+}\end{array}$ \\
\hline $\begin{array}{l}5 \\
\text { Dichotomous }\end{array}$ & $\begin{array}{l}\text { Lack of } \\
\text { funding. } \\
\text { Lack of } \\
\text { confidence. } \\
\text { No choice. }\end{array}$ & $\begin{array}{l}\text { Positive trust } \\
\text { in The } \\
\text { Environment } \\
\text { Agency. }\end{array}$ & $\begin{array}{l}\text { People protest } \\
\text { and write more, } \\
\text { and talk to local } \\
\text { councillors. }\end{array}$ & $\begin{array}{l}\text { High to } \\
\text { average } \\
\text { Knowledge } \\
\text { and } \\
\text { involvement }\end{array}$ & $\begin{array}{l}\text { Mostly } \\
\text { Males }\end{array}$ & $\begin{array}{l}\text { Older } \\
\text { Age } \\
\text { groups } \\
40+\end{array}$ \\
\hline
\end{tabular}


Table 11. Summary of Barriers, Motivations and Improvements, Levels of knowledge and involvement, Gender and Age Differences for the Five Factors.

Some difficulties experienced in engaging with a local population can, to an extent, be explained by the different perspectives identified. Recognising these differences, and accommodating them in engagement strategies is a key step in moving towards more acceptable flood management solutions. However, a better understanding of individuals' perspectives is needed before specific engagement strategies can be designed. The next stage in this research includes in-depth interviews with the participants loading on each of the factors, and a workshop to debate the findings and suggest appropriate strategies 